\title{
Rural Marketing
}

\section{Anurudra Bhanot}

Marketers have started looking at the large mass of consumers living in the rural areas whose purchasing power has been growing slowly but surely. Mass media had already started to make inroads into these areas. The low penetration of branded packaged products surely offered vast potential for growth in these markets. This chapter examines the differences between urban and rural markets and offers insights into how things may be done differently from a marketer's perspective to gain share of this lucrative and emerging market.

Over the last few decades, much has been written about rural markets and rural marketing. For a long time, marketers had remained focused on fulfilling the demand for products and services in cities where consumers were relatively easy to reach, had access to various forms of media, and had the purchasing power. However, with passage of time and increase in competition, the urban markets started saturating and growth slowed down. To realize growth needs they have begun their forays into the rural market segments. It is safe to say that they need different strategies to reach the rural markets because they are very different from urban markets and offer many different types of challenges to the marketers. 


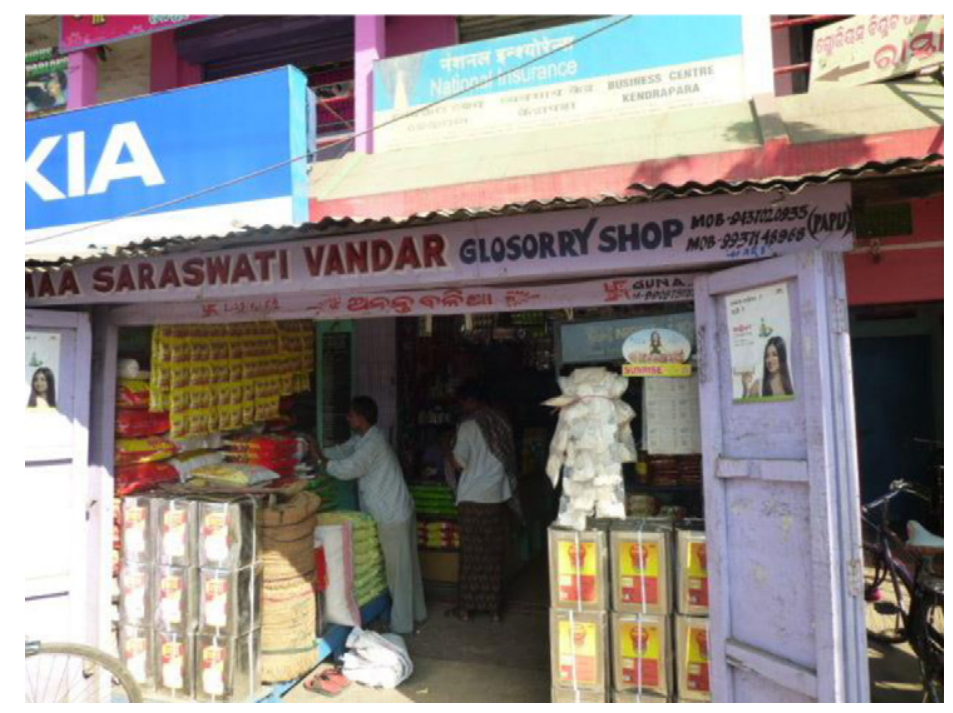

\section{Rural and Urban Markets - Whither Differences?}

Let us examine what makes the rural markets different and understand how some organizations came up with successful strategies to meet the challenges of charting marketing programs in a different territory.

The first thing that makes rural markets very different is the population density, which is very low, compared to urban areas. In many countries, population density is one of the criteria that define rural areas. In India, for instance, the rural areas are defined as

a. Areas that have a population density of less than 400 persons per square kilometer,

b. Areas that do not have a municipal body/notified area committee/army cantonment providing utility services such as clean drinking water, roads, electricity, sewerage system, and other civic services, and 
c. Areas where more than 25 percent of the male working population is engaged in agricultural pursuits.

According to the Indian government's census in 2011, over 833 million persons (69 percent of the total population) live in 640,930 villages. The remaining 377.10 million persons (31 percent of the total population) live in 7933 cities and towns. Table 1 shows the vast difference in rural and urban population spread.

The population density of India's four largest cities is shown in Table 2.

The table above shows that the population density of large cities is more than 60 times compared to that of the rural areas considering the highest population density of 400 persons per square kilometer for each village.

The second feature that separates rural areas from urban areas is the low- or non-availability of utility services. Since rural areas, by

Table 1: Spread of Population.

\begin{tabular}{lcccc}
\hline $\begin{array}{l}\text { Type of } \\
\text { Population }\end{array}$ & $\begin{array}{c}\text { Number of } \\
\text { Persons }\end{array}$ & $\begin{array}{c}\text { Percent } \\
\text { of Total }\end{array}$ & $\begin{array}{c}\text { Number of } \\
\text { Villages/Cities }\end{array}$ & $\begin{array}{c}\text { Persons per } \\
\text { Village/Town }\end{array}$ \\
\hline Rural & $833,463,448$ & 69 & 640,930 & 1300 \\
Urban & $377,106,125$ & 31 & 7933 & 47,536 \\
\hline
\end{tabular}

Source: Census of India (www.censusindia.gov.in).

Table 2: Population Density of India's Major Metro Cities.

\begin{tabular}{lrrc}
\hline City & \multicolumn{1}{c}{ Population } & Area $\left(\mathrm{km}^{2}\right)$ & Pop. Density \\
\hline Chennai & $4,681,087$ & 181 & 25,854 \\
Delhi & $11,007,835$ & 431 & 25,535 \\
Kolkata & $4,486,679$ & 185 & 24,252 \\
Mumbai & $12,478,447$ & 603 & 20,694 \\
India & $1,210,569,573$ & $3,287,590$ & 382 \\
\hline
\end{tabular}

Source: Population density in India. ${ }^{1}$ 
definition, do not have municipal bodies there is a large infrastructure gap when it comes to provision of utility services like electricity, roads, tele-communication, clean drinking water and sewerage system. Consider the contrast between urban and rural areas, in access to utility services (Table 3).

Table 3: Availability of Households to Amenities/Utility Services (Rural vs. Urban).

\begin{tabular}{|c|c|c|c|c|}
\hline \multirow[t]{2}{*}{ Facility } & \multirow[t]{2}{*}{ Location/Type } & \multicolumn{3}{|c|}{$\begin{array}{c}\text { Households having } \\
\text { Access }\end{array}$} \\
\hline & & Total & Rural & Urban \\
\hline \multirow[t]{4}{*}{$\begin{array}{l}\text { Drinking water } \\
\text { source }\end{array}$} & $\begin{array}{l}\text { Tapwater from } \\
\text { treated source }\end{array}$ & $32 \%$ & $18 \%$ & $62 \%$ \\
\hline & Handpump & $33 \%$ & $44 \%$ & $12 \%$ \\
\hline & Tubewell & $8 \%$ & $8 \%$ & $9 \%$ \\
\hline & $\begin{array}{l}\text { Other (pond, lake, } \\
\text { river, well) }\end{array}$ & $26 \%$ & $30 \%$ & $17 \%$ \\
\hline \multirow{3}{*}{$\begin{array}{l}\text { Location of } \\
\text { drinking water } \\
\text { source }\end{array}$} & Within premises & $47 \%$ & $35 \%$ & $71 \%$ \\
\hline & Near premises & $36 \%$ & $43 \%$ & $21 \%$ \\
\hline & Away & $18 \%$ & $22 \%$ & $8 \%$ \\
\hline \multirow{4}{*}{$\begin{array}{l}\text { Main source of } \\
\text { lighting }\end{array}$} & Electricity & $67 \%$ & $55 \%$ & $93 \%$ \\
\hline & Kerosene & $31 \%$ & $43 \%$ & $6 \%$ \\
\hline & Other & $1 \%$ & $1 \%$ & $0 \%$ \\
\hline & No lighting & $0 \%$ & $1 \%$ & $0 \%$ \\
\hline \multirow[t]{3}{*}{ Latrine facility } & Within premises & $47 \%$ & $31 \%$ & $81 \%$ \\
\hline & Public latrine & $3 \%$ & $2 \%$ & $6 \%$ \\
\hline & Open & $50 \%$ & $67 \%$ & $13 \%$ \\
\hline \multirow[t]{3}{*}{ Bathing facility } & Within premises & $42 \%$ & $25 \%$ & $78 \%$ \\
\hline & Community facility & $16 \%$ & $20 \%$ & $9 \%$ \\
\hline & No facility & $42 \%$ & $55 \%$ & $13 \%$ \\
\hline
\end{tabular}


Table 3: (Continued)

\begin{tabular}{llrrr}
\hline Facility & \multicolumn{1}{c}{ Location/Type } & \multicolumn{2}{c}{ Households having } \\
\cline { 3 - 4 } & & \multicolumn{3}{c}{ Access } \\
\cline { 2 - 4 } Waste water & Closed drainage & Rural & Urban \\
outlet connected & Open drainage & $18 \%$ & $6 \%$ & $45 \%$ \\
& No drainage & $33 \%$ & $31 \%$ & $37 \%$ \\
Type of fuel used & Fire-wood & $49 \%$ & $63 \%$ & $18 \%$ \\
for cooking & Piped gas/Gas cylinder & $49 \%$ & $63 \%$ & $20 \%$ \\
& Other fuels & $29 \%$ & $11 \%$ & $65 \%$ \\
Kitchen facility & Inside house & $22 \%$ & $26 \%$ & $15 \%$ \\
& Outside house & $87 \%$ & $83 \%$ & $96 \%$ \\
Communication / & Radio/Transistor & $12 \%$ & $16 \%$ & $4 \%$ \\
entertainment & Television & $20 \%$ & $17 \%$ & $25 \%$ \\
& Mobile phones & $47 \%$ & $33 \%$ & $77 \%$ \\
& Landphones & $53 \%$ & $48 \%$ & $64 \%$ \\
& Both mobile & $4 \%$ & $3 \%$ & $6 \%$ \\
& and & $6 \%$ & $3 \%$ & $12 \%$ \\
& landphones & & & \\
\hline
\end{tabular}

Source: Census of India (www.censusindia.gov.in).

The third feature that separates rural areas from urban areas is the big difference in income levels. A report by the Centre for Monitoring of Indian Economy (CMIE) ${ }^{\text {a }}$ reported that in 2013, the average household income in urban India was Rs. 240,172 while in rural areas it was Rs. 116,672. Because of the smaller size of

a. http:/ / www.consumer-pyramids.com/kommon/bin/sr.php?kall=wclrdhtm\&nvdt=2014 0303172910846\&nvpc=095000000000\&nvtype=INSIGHTS 
households in urban India, the per capita income of urban households was 2.2 times compared to the per capita income of rural households. One major reason for this wide difference is the practice of agriculture by the vast majority of families in rural areas and the fact that agricultural income varies widely by crops, availability of irrigation and agricultural inputs as it does by agroclimatic conditions in different regions.

The fourth feature that makes rural markets unique is the low levels of literacy, particularly female literacy. Table 4 shows the difference in male and female literacy rates for urban and rural India:

Table 4: Literacy Rates in India in 2011.

\begin{tabular}{lccc}
\hline Areas & All & Male & Female \\
\hline Rural & $77 \%$ & $86 \%$ & $67 \%$ \\
Urban & $90 \%$ & $94 \%$ & $85 \%$ \\
\hline
\end{tabular}

Source: Census of India (www.censusindia.gov.in).

\section{Challenges Related to 4Ps}

There are many other social, cultural, and environmental factors that make the rural markets unique and different from urban markets, but the features discussed above contribute the most.

Let us turn our attention to the challenges these factors pose to marketers for reaching the rural markets and consumers:

1. Product. If we look at the data on household electrification in villages, it is easy to understand why there is a low demand for consumer electronics like mixer-grinders, refrigerators or ceiling fans in the rural area. The same reason also explains why the market for dry cells was growing at a healthy rate of over 10 percent in rural areas when it was actually shrinking in urban areas. Data on use of cooking fuels explains the limited market for pressure cookers or gas burners in the rural areas (Table 3). 
Therefore, the first lesson marketers learnt was that everything that sells well in urban markets may not sell equally well in rural areas because of different consumer needs and support systems. But it is equally true that a small segment of affluent rural consumers aspire for products used by their urban counterparts. If marketer scan find a way of reaching them, the volumes can be sizeable given the large base of rural consumers. What we are saying is that in a country like India a 5 percent market share gain in rural areas could be equal to a 15 percent market share gain in urban areas. The difference is that the urban consumers are concentrated in smaller urban markets while the rural consumers are spread out across smaller villages. The challenge is to find cost effective ways of distributing the goods across number of villages. Maruti, India's largest car manufacturer began expanding its sales and service network to the rural markets six years ago - today one-third of its sales is coming from rural areas (see chapter end case study "Maruti's focus on rural market drives sales").

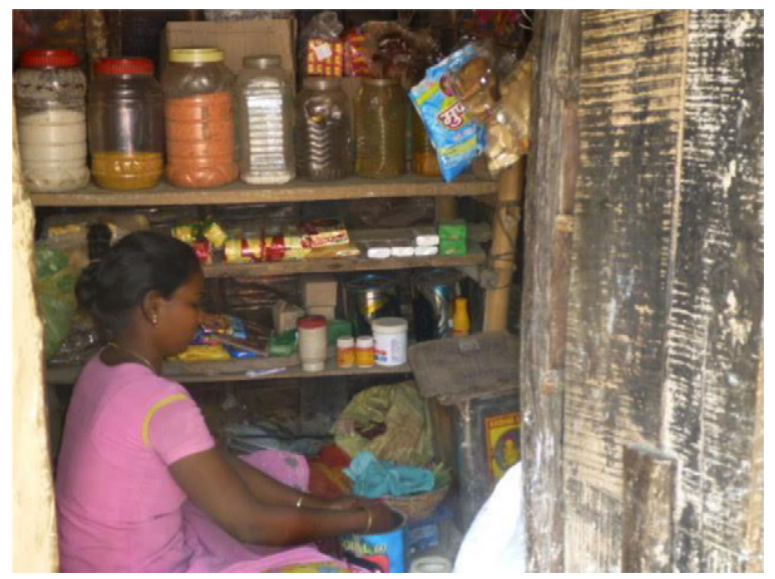

2. Price. The difference in urban and rural incomes explains the low spending patterns in rural areas on branded packaged good. Market research studies by numerous organizations 
showed that the average rural consumer has limited purchasing power compared to his/her urban counterpart. Marketers learnt that they must rethink technological and management processes to create "affordable" products for the rural consumers. Arvind Mills, the manufacturers of premium denim brands, created ready to stitch brand "Ruff \& Tuff" for the rural youth who aspired to wear denim jeans but could not afford to buy high priced readymade denims. "Ruff \& Tuff" started selling a complete package of denim cloth, stitching thread, buttons, and leather labels at a fraction of what the popular urban brands cost. The rural consumers could buy the "kit" and get their jeans custom stitched at the local tailor for a very reasonable price. "Nirma," the largest selling detergent brand in Asia, took on the multinational Unilever by producing a low-cost detergent packed in polythene bags and distributed in villages using local transport solutions like bicycle salesmen.

Another company that used smart thinking to penetrate rural markets was Cavincare that started marketing "Chic" shampoo in small sachets for one time use. Rural consumers started buying the sachets as they did not have to lock-in a lot of money in bigger packsizes. The success of "Chic" shampoo spawned a whole range of products in smaller pack sizes for rural markets from toothpaste to fairness creams as the companies discovered that the volumes from small packs were growing faster than large packs marketed in urban areas.

3. Promotion. Through mid-1980s and early 1990s, cable and satellite technology was penetrating the urban markets, but the rural markets could access only terrestrial television channels. In India, this meant being able to watch only the state-run TV channel "Doordarshan." To supplement advertising through the public broadcaster, companies used strategies like use of mobile audio-visual vans, participation in religious festivals and fairs where millions of rural consumers congregated, participation in weekly haat bazaars where 
buyers and sellers came together from nearby areas, and numerous other strategies like parading elephants or camels for new product launches. Companies also relied on cinema and outdoor advertising forms like wall-sites, bill-boards, and posters/tablets for creating local advertising.

By the late 1990s cable and satellite had started penetrating the semi-urban and semi-rural areas, and consumers started getting exposed to advertising messages playing on television, and FM radio. However, companies soon learnt that it was incorrect to assume that what appealed to the urban consumer would be liked in rural areas also. Given the different levels of literacy, different lifestyles, and cultural and linguistic differences in rural areas it became imminent that the advertisers needed to use local dialects, rural and folk motifs, culturally appropriate messages, and characters / storylines with whom the rural audiences associate easily. Advertisers and brand marketers started traveling to villages to understand how the rural audiences process their messages, and what clicks and what does not. In his article "Focused communication for rural India," ${ }^{2}$ R. V. Rajan, Chairman, Anugrah Madison Advertising, noted that tricky, clever, gimmicky, or even suggestive advertising does not work with the rural audience. "Slice of life" approaches, simple, and direct, using aspirational urban-looking models worked very well.

Soft drinks major Coca-cola was among the early marketers who created very successful campaigns like "Thanda Matlab Coca-Cola" (Cold means Coca-Cola) aimed specifically at rural and small town audiences.

4. Place. One of the most unique features of the rural markets is the spread of consumers over a large number of small villages. As discussed earlier, more than two-thirds of India's 1.2 billion consumers live in 640,930 villages. It is impossible to supply the products to small retail shops in each village especially small hamlets of 50-60 households that do not have an approach road and enough buyers to justify the high 
expense of transporting goods to such remote locations. When multinationals like Unilever, Colgate, Coca-Cola started analyzing the data on the spread of rural population they realized that it will take them years and billions of dollars to connect every retailer in the villages to their distribution network. They realized that it was important to prioritize the villages in which servicing the retailers would allow them to reach a larger number of consumers (hub and spoke strategy). Figure 1 shows that 20 percent of all the villages (with population above 2000 persons) accounted for almost 60 percent of the rural population.

Companies soon realized that focusing on one-fifth of the villages would allow them to reach 60 percent of the rural consumers, a strategy that itself was sufficient to ensure high growth in times when the urban markets were stagnating.

Companies also learnt that small shopkeepers from very small villages would often visit large villages nearby from where they would pick up branded packaged products and bring them back for re-selling in their villages. The retailers would often use their bicycle or popular modes of rural transport like pony-carts to economize on transport costs. As volumes started to grow, some

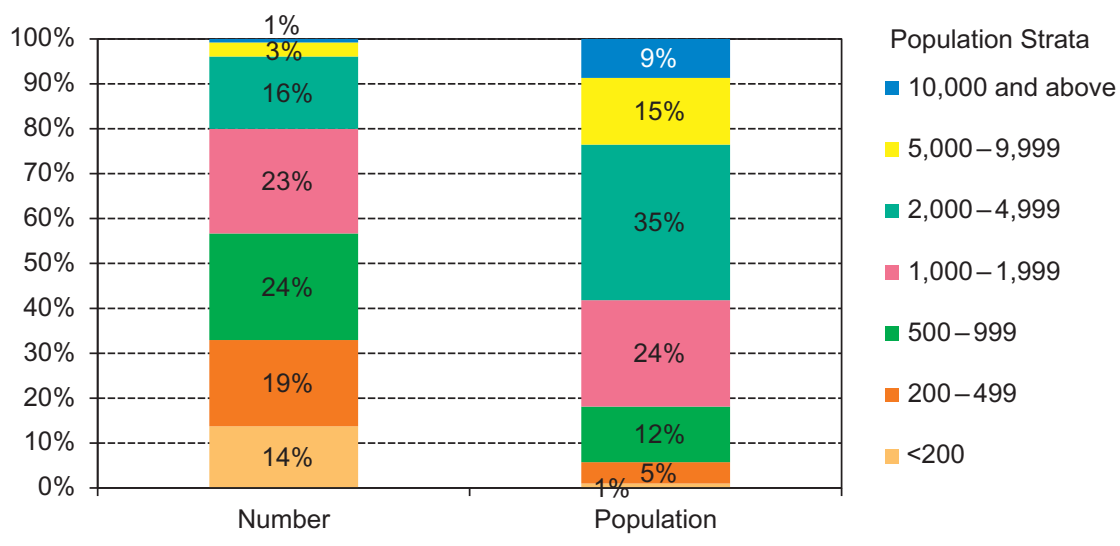

Figure 1: Population Spread by Size of Villages. Source: Census of India (www.censusindia.gov.in). 
enterprising shopkeepers started using motorcycles to bring bigger volumes of personal care and food products to their villages for re-selling.

In the meantime, companies like Amul, ITC Agro-products and many other organizations had begun to start using internet and mobile phones for creating networks of farmers who would act as both consumers and spokespersons for their products. The $\boldsymbol{e}$-choupal ${ }^{\mathrm{b}}$ network set up by ITC allowed the company to tackle the challenges posed by the unique features of Indian agriculture, characterized by fragmented farms, weak infrastructure and the involvement of numerous intermediaries, among others. The Amul success story through its Anand pattern of co-operatives ${ }^{c}$ had demonstrated that it was possible to source milk from small milk producers in small villages, process it in professionally managed dairy plants and sell milk to urban consumers. Amul was successfully using the milk procurement network to distribute cattle-feed and veterinary products to the dairy farmers in villages.

b. http://www.itcportal.com/businesses/agri-business/e-choupal.aspx

c. http://www.amuldairy.com/index.php/anand-pattern1 
Maruti - Focusing on Rural Markets

Anurudra Bhanot

\section{MARUTI SUZUKI INDIA}

Maruti Suzuki India Limited, is an automobile manufacturer in India, a subsidiary of Suzuki Motor Corporation of Japan. It manufactures and sells popular brands such as Swift, Zen, Swift, Alto, Omni, etc.

\section{MARUTI'S FOCUS ON RURAL MARKET DRIVES SALES}

Maruti Suzuki's six-year-old rural focus has earned rich dividends. Now, one-third of all cars sold by the company drive down to the hinterland.

Maruti's rural sales grew 16 percent in financial year 2013-2014. At 336,463 units, this segment comprises 32 percent of the car market leader's total sales spread over 93,500 villages, up from 44,374 villages where the company sold its cars in 2012-2013. Maruti, according to top officials, sees its non-metro push as the drive to the future.

"Our car sales in rural areas are now 32 percent of our total sales. Future growth of our industry will be more and more from non-metro cities and rural areas," Maruti chairman R. C. Bhargava said. "We continue to strengthen our sales and service structure in these areas."

The rural focus comes on the back of Maruti's strategy of hitting sales of three million units in the longer term. In his address to shareholders, Bhargava talked of parent Suzuki's investment in the new Gujarat plant freeing up capital for Maruti to "strengthen R\&D to develop and maintain the much larger number of models required to achieve sales of 3 million cars." Analysts say Maruti has managed to "crack" the rural market thanks to its focus on fuel efficiency and network expansion.

The company achieved a 3-15 percent increase in fuel efficiency last fiscal across all models "by working on different technologies and areas like optimization of 
crank and intake system, new low viscosity oil, use of new technologies for rolling resistance reduction of tyres etc." Maruti MD \& CEO Kenichi Ayukawa said in the address to shareholders.

Maruti has announced fuel efficiency as one of its top focuses for R\&D activity. On its agenda are reducing vehicle weight and cost and use of alternate material plus new technologies. Maruti saw its total R\&D spend as a percentage of total income increase from 1.17 percent in FY2012-2013 to 1.48 percent in FY2013-2014.

Of course, no village road show can work without service accessibility. Maruti, which has 3000 rural service outlets, is planning to expand that network by 200 this year. It is also planning to double its 1000-strong mobile service vans across rural markets.

Maruti's rural target began in the slowdown of 2008 but really came good in 2013 when the car market saw its worst slowdown in a decade. While the rest of the market ground to negative growth curve, Maruti saw its smaller/rural markets - with populations of less than 10,000 people growing around 14-15 percent.

Source: Case Study (http://timesofindia.indiatimes.com/business/india-business/ Marutis-focus-on-rural-market-drives-sales/articleshow/40312727.cms).

\section{QUESTIONS FOR DISCUSSION}

Read the case study "Maruti's focus on rural market drives sales" and answer the following questions:

1. What changes did Maruti make in their product design to manufacture cars suited to the needs of rural consumers?

2. Do you think Maruti's strategy of increasing its dealer network from 44,374 to 93,500 villages was an effective strategy for increasing sales? Why?

3. Why does Maruti need to expand its service network from 3,000 to 3,200 in the current year?

4. If you were the Sales Head at Maruti, would you allocate more resources for expanding the brick and mortar service network or would you allocate more resources to expand the mobile service vans across rural markets? Explain your reasons. 
5. You are the Marketing Head at Maruti and you have to brief the new advertising agency for creating a promotional campaign for rural markets. Prepare a short brief for the advertising team describing the profile of potential rural customers, the value proposition for the rural customers and media strategy for the rural markets.

\section{TIPS FOR DISCUSSION}

\section{Answer guide Q1:}

Maruti made fuel efficiency as one of its top focuses for R\&D activity. On its agenda were reducing vehicle weight and cost, and use of alternate material plus new technologies. The company achieved a 3-15 percent increase in fuel efficiency last fiscal across all models "by working on different technologies and areas like optimization of crank and intake system, new low viscosity oil, use of new technologies for rolling resistance reduction of tyres etc."

\section{Answer guide Q2:}

Maruti's strategy of increasing its dealer network from 44,374 to 93,500 villages was an effective strategy because it allowed the company to offer its product range to a larger number of prospective customers. By more than doubling its dealer network, the company was able to showcase its product range to more than two times the potential customers.

\section{Answer guide Q3:}

Once the cars are sold they will need regular servicing. If Maruti does not expand its service network simultaneously, the customers will have to travel far to get their cars serviced, and this will lead to customer dissatisfaction. This will impact the market expansion and growth, as the word of mouth spreads about Maruti's lack of service network in rural areas. This will potentially impact the sales of both new and preowned cars which is emerging a big market in rural areas.

\section{Answer guide Q4:}

I would allocate more money to expand the mobile service network through vans. Since a brick and mortar service center can service only a limited number of villages in the catchment area or vicinity, its running costs will become unviable forcing the company to shut it down. Also, the capacity utilization will be low given the density 
of car owners in rural areas. Mobile van-based service network has lower fixed costs and can be utilized to service larger number of clients over a wider area.

\section{Answer guide Q5:}

My brief would focus on promoting high mileage (fuel efficiency) and low maintenance costs as the key value proposition for rural customers. I would also brief the advertising agency to develop a media mix suitable for rural costumers based on their media consumption patterns and preferences. For the creative team, my brief would be use language, models, motifs, and story lines that the rural customers would easily be associated with that. 